\title{
Effect of the size of cuttings (length and diameter) on rooting in cuttings of apple clonal rootstock Merton 793
}

\author{
Pramod Verma $^{1 *}$, P. S. Chauhan ${ }^{2}$, J. S. Chandel ${ }^{1}$ and Manish Thakur ${ }^{1}$ \\ ${ }^{1}$ Department of Fruit Science, Dr. Yashwant Singh Parmar University of Horticulture and Forestry, Nauni, Solan \\ -173230 (H. P.), INDIA. \\ ${ }^{2}$ College of Horticulture, Dr. Yashwant Singh Parmar University of Horticulture and Forestry, Nauni, Solan - 173230 \\ (H.P.), INDIA \\ *Corresponding author. E-mail: verma.pramod92@gmail.com
}

Received: February 6, 2015; Revised received: June 26, 2015; Accepted: July 29, 2015

\begin{abstract}
The study was conducted in net house conditions of fruit Nursery block of Department of Fruit Science, Dr. Y. S. Parmar University of Horticulture and Forestry Nauni, Solan H.P. during 2012-2013 in order to evaluate the effect of size of cuttings (length and diameter) on rooting in cuttings of apple clonal rootstock Merton 793. Cuttings of length (L) viz. $15 \mathrm{~cm}, 25 \mathrm{~cm}, 35 \mathrm{~cm}, 45 \mathrm{~cm}$ and diameter ranges (D) viz. $0.75 \mathrm{~cm}-1.00 \mathrm{~cm}, 1.00 \mathrm{~cm}-1.25 \mathrm{~cm}$, $1.25-1.50 \mathrm{~cm}$ were taken. The experiment was laid out in randomized block design (factorial). The cuttings were treated with 2500 ppm IBA (Indole - 3 - butyric acid) as quick dip (10 - 15 seconds) before planting. The results revealed that the cuttings with treatment combination of length $(35 \mathrm{~cm})$ and diameter $(1.25 \mathrm{~cm}-1.50 \mathrm{~cm})$ recorded the highest rooting of cuttings $(65 \%)$, number of primary roots $(5.00)$, length of primary roots $(28.43 \mathrm{~cm})$, diameter of primary roots $(3.25 \mathrm{~mm})$, fresh weight of roots $(3.67 \mathrm{~g})$ and dry weight of roots $(2.59 \mathrm{~g})$. Hence it is concluded that cuttings of length of $35 \mathrm{~cm}$ and diameter of $1.25 \mathrm{~cm}$ to $1.50 \mathrm{~cm}$ was most suitable for propagation. However, the cuttings of shorter length and diameter, are also able to result in rooting with lower success, therefore, these cuttings would be helpful in case of scarce availability of propagating material.
\end{abstract}

Keywords: Apple, Merton 793, Rooting percentage, Size of cuttings

\section{INTRODUCTION}

The cultivated apple (Malus domestica Borkh.) is a member of family Rosaceae and sub-family Pomoideae. Apple is an economically important fruit tree around the world (Karakurt, 2006; Aslantas and Karakurt, 2007). In India, apple is mainly grown in North Western Himalayan region comprising states of Jammu and Kashmir, Himachal Pradesh and Uttrakhand. Apple plants are traditionally propagated through grafting and budding on seedling stock in the nursery. Though, clonal rootstocks are used commercially all over the world but, seedlings still continues to be the most commonly used rootstock in India, due to unavailability of elite propagating material of clonal rootstock (Negi, 2011).

Apple clonal rootstocks are conventionally propagated through mound layering (stooling). One of the convenient methods of clonal propagation is through hardwood cuttings (Hartmann et al., 2002). Among the clonal rootstock Merton 793, MM 111 and MM 106 are more suitable for agro climatic conditions of North West Himalayas. Merton 793 has been proved to be suitable rootstock for interplanting of old orchards because of its adaptability to a wider range of soil, precocious as compared to seedling rootstocks, vigorous, resistant to woolly apple aphid, collar rot and tolerant to replant problem. Merton 793 is cross between M 2 and Northern Spy, developed by East Malling and John Innes, Horticultural Institute in Merton England, which is a suitable alternative to seedling stock especially in replantation of senile orchards (Webster and Wertheim, 2003).

Rooting in Merton 793 rootstock is difficult and certain factors such as length, diameter, collection date and degree of hardening of the cuttings, injury and heat treatment of the cuttings and the treatment concentrations of auxin-like compounds (Tsipouridis et al., 2003), apart from these factors rooting hormones, planting time, maturity of the stock plants and propagation environment affect the rooting of stem cuttings (Bhusal et al., 2001). Hartmann et al. (2009) reported that the length of hardwood cuttings may vary from 10 to $76 \mathrm{~cm}$ and diameter of the cuttings may range from 0.6 to $2.5 \mathrm{~cm}$, to induce rooting and enhance root growth depending on the fruit species. For successful rooting in cuttings, it must have at least two or more nodes per cuttings and the basal (bottom) cut be made usually just below a node and the top cut 1.3 to $2.5 \mathrm{~cm}$ above a node are essential.

Clonal propagation of rootstocks through stooling and using hardwood of arial portion as cuttings is of 
special importance as it is beneficial tool to increase the production of rootstocks utilizing the arial portion of stool layers above grafting point. The stool layers above grafting point, consist of more than $80 \%$ of its length goes unutilized and waste. This part of rootstock can be used as hard wood cuttings to produce rooted plantlets and increase multiplication rate of clonal rootstocks even if the rooting success is not appreciably high (Negi, 2011). Keeping in view all these facts, the experiment was conducted in order to study the effect of size of cuttings (length and diameter) on rooting in cuttings of apple clonal rootstock Merton 793.

\section{MATERIALS AND METHODS}

The present investigation was undertaken in net house condition of fruit Nursery block of Department of Fruit Science, Dr. Y. S. Parmar University of Horticulture and Forestry Nauni, Solan H.P. during 2012-2013. The one year old stool shoots ranging from $0.75 \mathrm{~cm}-1.50$ $\mathrm{cm}$ in diameter (D) and $15 \mathrm{~cm}$ to $45 \mathrm{~cm}$ in length (L) were collected in the month of January on 12/01/2012 from arial portion of rooted mound layer stool of Merton 793, during dormancy. A slant cut was given slightly above a node on the apical end and longitudinal wounding cut of $1.00-2.00 \mathrm{~cm}$ were made at basal end of cuttings to facilitate absorption of IBA. Nursery beds were prepared by mixing coco peat, sand and forest soil in the ratio $(1: 1: 1 ; \mathrm{v} / \mathrm{v})$. Rooting media was thoroughly mixed and nursery beds of $2 \mathrm{~m} \times 1 \mathrm{~m}$ size were prepared in the net house. The cuttings were planted at a spacing of $10 \mathrm{~cm}$ row to row and $7.5 \mathrm{~cm}$ apart in the row. The cuttings were dipped in 2500 ppm IBA for $10-15$ seconds before planting.

In this experiment, the percentage of rooting was calculated and number, length and diameter, fresh and dry weight of rooted cuttings were measured (Hartmann et al., 2002). In all, there were 12 treatment combinations of length and diameter of cuttings each having 4 length $(15 \mathrm{~cm}, 25 \mathrm{~cm}, 35 \mathrm{~cm}, 45 \mathrm{~cm})$ and 3 diameter ranges $(0.75 \mathrm{~cm}-1.00 \mathrm{~cm}, 1.00 \mathrm{~cm}-1.25$ $\mathrm{cm}, 1.25-1.50 \mathrm{~cm})$ replicated thrice in a randomized block design (Factorial). The data on percentage were statistically analyzed using arc sine transformation to treat the data for removing skewness (Gomez and Gomez, 1984). The level of significance for different variables was tested at 5 per cent value of significance.

\section{RESULTS AND DISCUSSION}

Based on the result presented in Table 1, the highest rooting percentage $(58.89 \%)$ was recorded in cuttings of length $35 \mathrm{~cm}$ and $37.50 \%$ rooting percentage in cuttings of diameter $1.25 \mathrm{~cm}-1.50 \mathrm{~cm}$, which was statistically higher than any other treatments. Contrastingly, the minimum rooting $(9.44 \%)$ was obtained in cuttings of length $15 \mathrm{~cm}$ and $30 \%$ rooting was observed in cuttings of diameter $0.75-1.00 \mathrm{~cm}$. However, the interaction effect has non-significant effect on percentage of rooted cuttings. The highest rooting percentage $(65.00 \%)$ was recorded in combination with $35 \mathrm{~cm}$ length and $1.25 \mathrm{~cm}-1.50 \mathrm{~cm}$ thick cuttings, whereas the lowest $(6.67 \%)$ was observed in the treatment combination of $15 \mathrm{~cm}$ length and 0.75 $-1.00 \mathrm{~cm}$ thick cuttings. These results indicate that different size of cuttings with respect to length and diameter has exhibited a significant influence on rooting of cuttings. In addition, exogenously applied auxin (IBA) break starch into simple sugars, which is needed to greater extent for production of new cells. IBA may enhance rooting via increase of internal free IBA or many synergistically modify the action of IAA or endogenous synthesis of IAA. IBA can enhance tissue sensitivity to IAA and increase rooting (Vander Krieken et al., 1993). Markovic et al. (2014) reported highest rooting percentage $(96.7 \%)$ in cornelian cherry by using terminal cuttings with current season's wood only, treated with $1 \%$ IBA (powder dip).

Length and diameter of cuttings exerts a significant effect on number of primary roots of cuttings (Table

Table 1. Effect of size of cuttings length and diameter on per cent rooting of cuttings and number of primary roots per cuttings of apple clonal rootstock Merton 793 (Values are of 3 replications each of treatment combination).

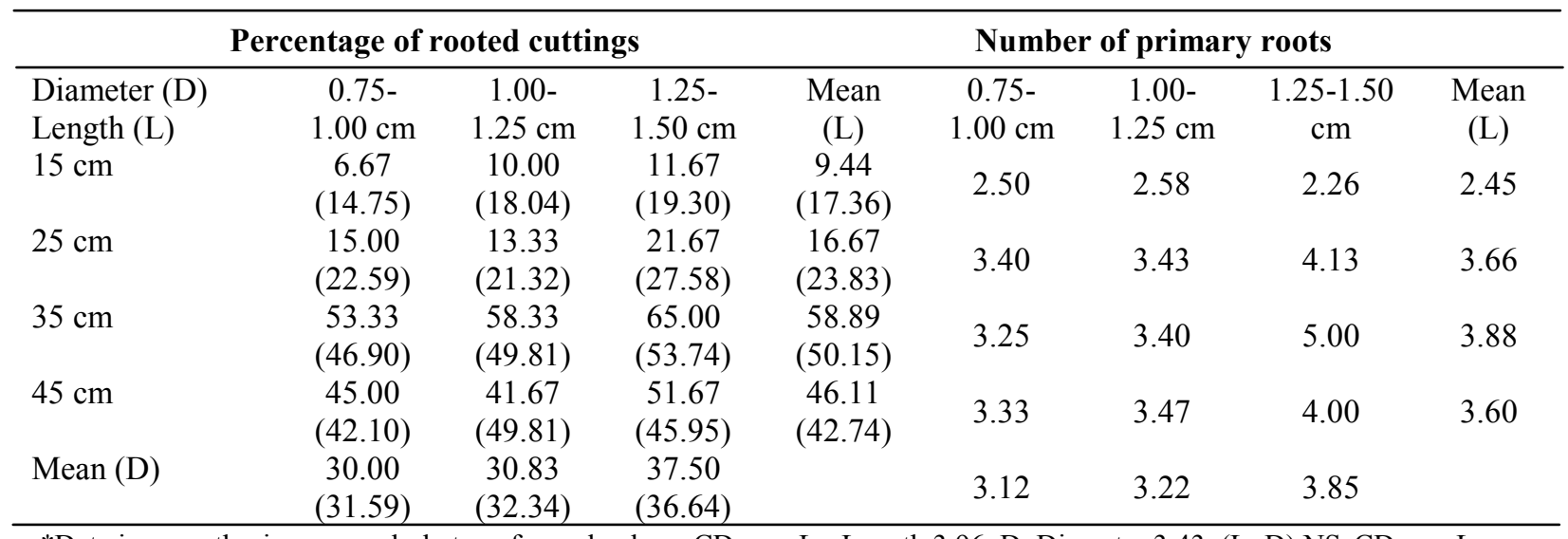

*Data in parenthesis are angularly transformed values, $\mathrm{CD}_{(0.05)}$ L - Length 3.96, D-Diameter 3.43, $(\mathrm{L} \times \mathrm{D}) \mathrm{NS}, \mathrm{CD}_{(0.05)}, \mathrm{L}$ - Length 0.40 , D - Diameter 0.35, (L×D) 0.70 
Table 2. Effect of size of cuttings length and diameter on length and diameter of primary roots of cuttings of apple clonal rootstock Merton 793 (Values are of 3 replications each of treatment combination).

\begin{tabular}{|c|c|c|c|c|c|c|c|c|}
\hline \multicolumn{4}{|c|}{ Length of primary roots $(\mathrm{cm})$} & \multicolumn{5}{|c|}{ Diameter of primary roots $(\mathrm{mm})$} \\
\hline Diameter(D) & $\begin{array}{c}0.75- \\
1.00 \mathrm{~cm}\end{array}$ & $\begin{array}{c}1.00- \\
1.25 \mathrm{~cm}\end{array}$ & $\begin{array}{c}1.25- \\
1.50 \mathrm{~cm}\end{array}$ & $\begin{array}{c}\text { Mean } \\
\text { (L) }\end{array}$ & $\begin{array}{c}0.75-1.00 \\
\mathrm{~cm}\end{array}$ & $\begin{array}{c}1.00- \\
1.25 \mathrm{~cm}\end{array}$ & $\begin{array}{c}1.25-1.50 \\
\mathrm{~cm}\end{array}$ & $\begin{array}{c}\text { Mean } \\
\text { (L) }\end{array}$ \\
\hline $15 \mathrm{~cm}$ & 14.11 & 16.81 & 23.11 & 18.01 & 0.98 & 1.45 & 2.06 & 1.50 \\
\hline $25 \mathrm{~cm}$ & 23.65 & 23.72 & 26.43 & 24.60 & 2.07 & 2.24 & 2.67 & 2.33 \\
\hline $35 \mathrm{~cm}$ & 17.12 & 17.29 & 28.43 & 20.95 & 1.61 & 1.82 & 3.25 & 2.22 \\
\hline $45 \mathrm{~cm}$ & 23.33 & 24.52 & 26.36 & 24.74 & 2.57 & 2.71 & 3.22 & 2.83 \\
\hline Mean (D) & 19.55 & 20.58 & 26.08 & & 1.81 & 2.05 & 2.80 & \\
\hline
\end{tabular}

Table 3. Effect of size of cuttings length and diameter on fresh weight and dry weight of roots of cuttings of apple clonal rootstock Merton 793 (Values are of 3 replications each of treatment combination).

\begin{tabular}{|c|c|c|c|c|c|c|c|c|}
\hline \multicolumn{4}{|c|}{$\begin{array}{l}\text { Fresh weight of roots (g) } \\
\end{array}$} & \multicolumn{5}{|c|}{ Dry weight of roots $(\mathrm{g})$} \\
\hline Diameter (D) & $\begin{array}{c}0.75-1.00 \\
\mathrm{~cm}\end{array}$ & $\begin{array}{c}1.00-1.25 \\
\mathrm{~cm}\end{array}$ & $\begin{array}{c}1.25- \\
1.50 \mathrm{~cm}\end{array}$ & $\begin{array}{l}\text { Mean } \\
\text { (L) }\end{array}$ & $\begin{array}{c}0.75-1.00 \\
\mathrm{~cm}\end{array}$ & $\begin{array}{c}1.00- \\
1.25 \mathrm{~cm}\end{array}$ & $\begin{array}{c}1.25-1.50 \\
\mathrm{~cm}\end{array}$ & $\begin{array}{l}\text { Mean } \\
\text { (L) }\end{array}$ \\
\hline Length (L) & & & & & & & & \\
\hline $15 \mathrm{~cm}$ & 1.08 & 1.14 & 1.90 & 1.37 & 0.50 & 0.60 & 0.78 & 0.63 \\
\hline $25 \mathrm{~cm}$ & 2.57 & 2.52 & 3.37 & 2.82 & 1.32 & 1.55 & 1.75 & 1.54 \\
\hline $35 \mathrm{~cm}$ & 1.24 & 1.24 & 3.67 & 2.05 & 0.43 & 0.45 & 2.59 & 1.16 \\
\hline $45 \mathrm{~cm}$ & 2.64 & 2.90 & 3.35 & 2.96 & 1.85 & 2.20 & 2.23 & 2.09 \\
\hline Mean (D) & 1.88 & 1.95 & 3.07 & & 1.03 & 1.20 & 1.84 & \\
\hline
\end{tabular}

1). The significantly highest number of primary roots (3.88) was recorded in cuttings with length $35 \mathrm{~cm}$ and lowest number of primary roots 2.45 was recorded in cuttings of $15 \mathrm{~cm}$ length. However, the maximum number of primary roots (3.85) was recorded in cuttings of diameter $1.25 \mathrm{~cm}-1.50 \mathrm{~cm}$ and minimum number of primary roots 3.12 was observed in cuttings of diameter of $0.75-1.00 \mathrm{~cm}$. The interaction of length and diameter also exerted a significant effect on number of primary roots, as the significantly highest number of primary roots per cuttings (5.00) was found in cuttings with treatment combination of length $35 \mathrm{~cm}$ and diameter $1.25 \mathrm{~cm}-1.50 \mathrm{~cm}$. The lowest number of primary roots $(2.50)$ was recorded in cuttings with treatment combination of length $15 \mathrm{~cm}$ and diameter $0.75-1.00 \mathrm{~cm}$. Similar result were reported by Stefancic et al. (2005) who reported average (6.5) roots per rooted cuttings in cherry Gisela 5 with IBA treatments. Gautam et al. (2010) reported that root induction was higher in cuttings with length ranging between $10 \mathrm{~cm}$ and $15 \mathrm{~cm}$ long than cuttings of length $5 \mathrm{~cm}$ in juvenile apical shoot cuttings of guava. Markovic et al. (2014) obtained highest mean number of primary roots per cuttings (12.9) using terminal cuttings with current season's wood only, treated with 1\% IBA (powder dip) in cornelian cherry.

In the present study the different size of cuttings length and diameter has exhibited a significant effect on length and diameter of primary roots (Table 2). As the maximum length of primary roots $(24.74 \mathrm{~cm})$ and diameter of primary roots $(2.83 \mathrm{~mm})$ was observed in cuttings of length $45 \mathrm{~cm}$. However, the minimum length of primary roots $(18.01 \mathrm{~cm})$ and diameter of primary roots $(1.50 \mathrm{~mm})$ was recorded in cuttings of length $15 \mathrm{~cm}$. With respect to diameter, maximum length of roots $(26.08 \mathrm{~cm})$ and diameter of roots $(2.80$ $\mathrm{mm})$ was recorded in cuttings of diameter $1.25 \mathrm{~cm}$ $-1.50 \mathrm{~cm}$. The minimum length of roots $(19.55 \mathrm{~cm})$ and diameter of primary roots $(1.81 \mathrm{~mm})$ was observed in cuttings of diameter $0.75-1.00 \mathrm{~cm}$. So far as the interaction of length and diameter of cuttings is concerned, the maximum length of primary roots $(28.43 \mathrm{~cm})$ and diameter of primary roots $(3.25 \mathrm{~mm})$ was found in cuttings with treatment combination of $\mathrm{L}$ - $35 \mathrm{~cm}$; D - $1.25 \mathrm{~cm}-1.50 \mathrm{~cm}$. Whereas, the minimum length of primary roots $(14.11 \mathrm{~cm})$ and diameter of primary roots $(0.98 \mathrm{~mm})$ was recorded in cuttings with treatment combination of L - $15 \mathrm{~cm}$; D $-0.75-1.00 \mathrm{~cm}$. There might be a role of early initials of root with length of primary roots, which occurred in longer and thicker roots better as a result of sufficiently carbohydrates reserves, nutrients and optimum hormonal supply. Longer cuttings produced long primary roots which are proportionally thicker. Long cuttings, when they are to be used as rootstock for fruit trees, permit the insertion of the cultivar bud into the original cuttings following rooting, rather than into a smaller new shoot arising from the original cutting (Hartmann et al., 2009). Dvin et al. (2011) reported maximum root length $(9.83 \mathrm{~cm})$ in hardwood cuttings of apple clonal rootstock MM 111 when treated with IBA $1500 \mathrm{ppm}$ and planted in coco peat 
+ perlite medium.

The result obtained in the present studies revealed that size of cuttings exerted a significant effect on fresh weight and dry weight of roots (Table 3). The maximum fresh weight of roots $(2.96 \mathrm{~g})$ and dry weight of roots $(2.09 \mathrm{~g})$ was recorded in cuttings of length $45 \mathrm{~cm}$, whereas, the minimum fresh weight of roots $(1.37 \mathrm{~g})$ and dry weight of roots $(0.63 \mathrm{~g})$ was observed in cuttings of length $15 \mathrm{~cm}$, irrespective of length. So far as diameter of cuttings is concerned, the maximum fresh weight of roots $(3.07 \mathrm{~g})$ and dry weight of roots $(1.84 \mathrm{~g})$ was found in cuttings of diameter $1.25 \mathrm{~cm}-1.50 \mathrm{~cm}$. However, the minimum fresh weight of roots $(1.88 \mathrm{~g})$ and dry weight of roots $(1.03 \mathrm{~g})$ was recorded in cuttings of diameter 0.75 $-1.00 \mathrm{~cm}$, irrespective of diameter. The interaction between sizes of cuttings was found to have significant effect on fresh weight and dry weight of roots. The maximum fresh weight of roots $(3.67 \mathrm{~g})$ and dry weight of roots $(2.59 \mathrm{~g})$ was recorded in cuttings with treatment combination of $\mathrm{L}-35 \mathrm{~cm} ; \mathrm{D}-1.25 \mathrm{~cm}$ $-1.50 \mathrm{~cm}$. The longest and thickest cuttings of $35 \mathrm{~cm}$ to $45 \mathrm{~cm}$ long and $1.25 \mathrm{~cm}$ to $1.50 \mathrm{~cm}$ thick cuttings and their combination resulted in highest fresh and dry weight in comparison to shortest and thinnest cutting mainly due to higher metabolic reserves for root initiation and growth as well as higher rooting and growth of roots in $35 \mathrm{~cm}$ to $45 \mathrm{~cm}$ long and $1.25 \mathrm{~cm}$ to $1.50 \mathrm{~cm}$ thick cuttings may accounted for higher fresh and dry weight of the roots in the present study. Hassanpour and Shiri (2014) reported maximum fresh weight $(4.17 \mathrm{~g})$ and dry weight $(1.17 \mathrm{~g})$ of roots in the genotype $\mathrm{C} 3$ of rooted stem cuttings of Iranian cornelian cherry (Cornus mas L.)

\section{Conclusion}

The study reveals that the cuttings of length $35 \mathrm{~cm}$ and diameter of $1.25 \mathrm{~cm}$ to $1.50 \mathrm{~cm}$ can be used as source of vegetative propagation for apple clonal rootstock Merton 793. As, these cuttings gave better rooting, number of roots, length and diameter of primary roots, fresh and dry weight of roots. However, it can be opined that the cuttings of shorter length and diameter, are also able to result in rooting, shoot growth with lower success and could be used in case of scares availability of propagating material.

\section{REFERENCES}

Aslantas, R. and Karakurt, H. (2007). The changes in vegetative growth, pomological characteristics and chemical contents of some apple cultivars growing in two different altitude sea levels. Turkish with English Abstract. Turkish V. National Horticulture Congress, 7:842-846.

Bhusal, R.C. Mizutani, F. Moon, D.G. and Rutto, K.L. (2001). Propagation of citrus by stem cuttings and seasonal variation in rooting capacity. Pakistan Journal of Biological Sciences, 4: 1294-1298.

Dvin, S. R. Moghadam, E. G. and Kiani, M. (2011). Rooting response of hardwood cuttings of MM 111 apple clonal rootstock to indolebutyric acid and rooting media. Asian Journal of Applied Sciences, 4(4): 453-458.

Gautam, N.N. Singh, Kripal, Singh, B. Seal, Shubhendu, Goel, A. and Goel, V.L. (2010). Studies on clonal multiplication of Guava (Psidium guajava L.) through cuttings under controlled conditions. Australian Journal of Crop science, 4(9): 666-669.

Gomez, K.A. and Gomez, A.A. (1984). In: Statistical Procedure for Agricultural Research $2^{\text {nd }}$ ed. New York: Willey Interscience. 304-309 pp.

Hartmann, H.T. Kester, D.E. Davies, F.T. and Geneva, R.L. (2002). Plant propagation: principles and practices, $7^{\text {th }}$ Edition. 1:410.

Hartmann, H.T. Kester, D.E. Fred, T.D. Robert, L. Geneve, R.L. (2009). In: Plant Propagation Principles and Practices, $7^{\text {th }}$ edition, Prentice Hall, New Delhi.1039 p.

Hassanpour, H. and Shiri, M.A. (2014). Propagation of Iranian cornelian cherry (Cornus mas L.) by rooted stem cuttings. Notulae Scientia Biologicae, 6(2): 192-195.

Karakurt, H. (2006). Determination of effects of some bacteria strains on fruit setting, fruit properties and plant growth on apple. M.Sc. Thesis Graduate School of Natural and Applied Sciences, Ataturk University.

Markovic, M. Grbic, M. and Djukic M. (2014). Effects of cutting type and method of IBA application on rooting of softwood cuttings from elite tree of cornelian cherry (Cornus mas L.) from Belgrade area. Silva Balacania, 15(1): 30-37.

Negi, A. (2011). Studies on the multiplication of apple clonal rootstocks through cuttings. M.Sc. Thesis Dr. Yashwant Singh Parmar University of Horticulture and Forestry Nauni, Solan Himachal Pradesh, INDIA.

Stefancic, M. Stampar, F. and Osterc, G. (2005). Influence of IAA and IBA on root development and quality of Prunus 'GiSelA 5' leafy cuttings. Horticulture Science, 40(7):2052-2055.

Tsipouridis, C. Thomidis, T. and Isaakidis, A. (2003). Rooting of peach hardwood and semi hardwood cuttings. Australian Journal of Experimental Agriculture, 43: 1363-1368.

Vander Krieken, W.M. Breteler, H. Visser, M.H.M. and Mavridou, D. (1993). The role of the conversion of IBA into IAA on root regeneration in apple: introduction of a test system. Plant Cell Reports, 12: 203-206.

Webster, A.D. and Wertheim, S.J. (2003). Apple rootstocks. In: Ferre, D.C. and Warrington, I.J. (eds.). Apples: Botany, Production and uses. $91-124$ pp. 